\title{
Pengaruh Latihan Relaksasi Otot Progresif terhadap Kualitas Tidur Lansia
}

\author{
Sulidah ${ }^{1}$, Ahmad Yamin ${ }^{2}$, Raini Diah Susanti ${ }^{2}$ \\ ${ }^{1}$ Akademisi pada Jurusan Keperawatan, Fakultas llmu Kesehatan Universitas Borneo Tarakan, \\ ${ }^{2}$ Fakultas Keperawatan, Universitas Padjadjaran \\ Email : sulidah@borneo.ac.id \& sulidah06@gmail.com
}

\begin{abstract}
Abstrak
Lansia merupakan kelompok orang yang paling sering mengalami penurunan kualitas tidur. Beberapa penelitian menunjukkan manfaat latihan relaksasi otot progresif untuk menghadirkan rasa nyaman yang dibutuhkan dalam mereduksi penyebab gangguan tidur. Penelitian ini untuk mengidentifikasi pengaruh relaksasi otot progresif terhadap kualitas tidur lansia. Rancangan penelitian ini Quasi Experimental dengan pendekatan Pretest-Posttest Control Group Design. Sampel diambil secara Purposive Sampling. Besar sampel 51 responden, terdiri dari 26 responden kelompok intervensi dan 25 responden kelompok kontrol. Kelompok intervensi melakukan latihan relaksasi otot progresif selama empat minggu. Kualitas tidur diukur sebelum dan sesudah latihan relaksasi otot progresif menggunakan instrumen PSQI. Pengukuran dilakukan empat kali, yaitu sebelum intervensi (pre test), dua minggu setelah intervensi (post test 1), tiga minggu setelah intervensi (post test 2), dan empat minggu setelah intervensi (post test 3). Data dianalisis menggunakan t test dan Repeated Anova. Hasil Uji t berpasangan kelompok intervensi menunjukkan nilai t hitung $>\mathrm{t}$ tabel, dengan $\mathrm{p}=0,000$. Pada kelompok kontrol diperoleh nilai t hitung $<\mathrm{t}$ tabel, dengan $\mathrm{p}>0,05$. Uji Repeated Anova memeroleh nilai F hitung $(71,415)>\mathrm{F}$ tabel $(3,89)$ dengan $\mathrm{p}=0,000$. Uji t tidak berpasangan didapatkan skor pretest, posttest 1 , posttest 2 dan posttest 3 berbeda signifikan antara kelompok intervensi dan kelompok kontrol dengan $\mathrm{p}<0,05$. Rata-rata skor PSQI kelompok intervensi menunjukkan kecenderungan penurunan setelah latihan relaksasi otot progresif, sedang kelompok kontrol tidak menunjukkan perubahan skor secara bermakna. Hal ini dimungkinkan karena latihan relaksasi otot progresif bermanfaat menimbulkan respon tenang, nyaman, dan rileks. Implikasi penelitian ini bahwa latihan relaksasi otot progresif secara bermakna meningkatkan kualitas tidur lansia sehingga dapat dipertimbangkan sebagai terapi komplementer dalam tatalaksana gangguan tidur pada lansia sebagai tindakan mandiri keperawatan.
\end{abstract}

Kata kunci: Kualitas tidur, lansia, relaksasi otot progresif.

\section{The Effect of Progressive Muscle Relaxation Exercise towards Older People's Quality of Sleep}

\begin{abstract}
Older people are the group of people who often experience the decreasing of quality of sleep. Few studies showed the benefit of progressive muscle relaxation exercise to give comfort that is needed to reduce the cause of sleep disturbance. This study aimed to examine the effect of progressive muscle relaxation exercise towards older people's quality of sleep. The research design is quasi experimental using pretest-posttest control group design. The sample were recruited using purposive sampling. The total sample were 51 participant which consist of 26 participants in intervention group and 25 participants in control group. Intervention group were conducted progressive muscle relaxation exercise for four weeks. The quality of sleep were measured before and after the exercise using PSQI instrument. The measurements were conducted four times, which were before intervention (pretest), two weeks after intervention (posttest 1), three weeks after intervention (posttest 2), and four weeks after intervention (posttest $3)$. The data were analyzed using t-test and Repeated ANOVA. The paired t-test for intervention group showed that the score of counted $t>$ table $t$, with $p=0.000$. In the control group, the results showed that counted $t<$ table $t$ score, $p>0.005$. The repeated ANOVA showed that counted F (71.415) $>$ table F (3.89) with $p=0.000$. Independent $\mathrm{t}$-test showed that scores of pretest, posttest 1 , posttest 2 and posttest 3 were different significantly between intervention and control groups with $\mathrm{p}<0.05$. The average PSQI scores in intervention group showed a tendency of decreasing after progressive muscle relaxation exercise, while in the control group there was no significant changes in the scores. This is because the progressive muscle relaxation exercise is benefit to give calming, comforting and relaxing responses. The implication of this study is that progressive muscle relaxation exercise can significantly improve the quality of sleep of older people so that this exercise can be considered as a complementary therapy for management of sleep disturbance among older people as an independent nursing care.
\end{abstract}

Keywords: Older people, progressive muscle relaxation exercise, quality of sleep. 
Sulidah: Pengaruh Latihan Relaksasi Otot Progresif terhadap Kualitas Tidur Lansia

\section{Pendahuluan}

Faktor usia menyebabkan lansia menghadapi banyak keterbatasan sehingga memerlukan bantuan peningkatan kesejahteraan sosialnya (Samsudrajat, 2012). Kualitas hidup yang baik akan membawa lansia tetap mampu hidup produktif dalam keterbatasannya. Sebaliknya, penurunan kualitas hidup justru membuat lansia menjadi manusia yang tidak produktif, bahkan tergantung pada bantuan pihak lain. Penurunan kualitas hidup antara lain disebabkan oleh gangguan tidur sebagai akibat proses penuaan. Maka penanganan gangguan tidur sesungguhnya merupakan upaya peningkatan kualitas hidup lansia. Hal ini penting dilakukan mengingat populasi penduduk lansia terus bertambah. Jumlah penduduk lansia tahun 2014 tercatat 19,2 juta jiwa, meningkat pesat dibanding data tahun 1971 sebesar 5,3 juta jiwa (Kemenkes RI, 2015). Bahkan pada tahun 2020 diperkirakan akan terjadi ledakan penduduk lansia menjadi 28,8 juta jiwa atau sebesar $11,34 \%$ (Fatimah, 2012).

Fase lansia membawa perubahan organobiologik karena makin menuanya organ-organ tubuh. Salah satu dampak proses menua yang lazim terjadi adalah perubahan pola tidur. Seorang lansia akan lebih sering terjaga pada malam hari sehingga total waktu tidur malamnya berkurang (Marchira, 2007). Meskipun secara fisiologis kebutuhan tidur lansia berkurang tetapi hendaknya ketidakcukupan kuantitas dapat diimbangi dengan kualitas tidur. Tidur yang berkualitas meskipun kuantitasnya sedikit tetap lebih baik dibanding waktu tidur yang panjang tetapi tidak berkualitas. Menurut Madjid (2008), tidur yang berkualitas adalah keadaan tidur yang dalam, tidak mudah terbangun, dapat mencapai mimpi, dan ketika bangun tubuh menjadi lebih segar, merasakan kepuasan tidur dan bebas dari ketegangan.

Jenis gangguan tidur yang dialami lansia bervariasi. Menurut Association of Sleep Disorder Centers (1999) sebagaimana dikutip Montagna \& Chokroverty (2011), ada empat jenis gangguan tidur yang berat pada lansia, yaitu 1) Disorder of initiating and maintaining sleep, 2) Disorder of the excessive somnolence, 3) Abnormal of sleep behavior, dan (4) Disorder of sleep wake cycle. Insomnia merupakan bentuk gangguan tidur yang termasuk dalam kelompok pertama dan paling banyak dikeluhkan oleh lansia.

Faktor yang memengaruhi gangguan tidur juga variatif. Wolkove, dkk. (2007) dan Crowley (2011) mengidentifikasi faktor-faktor yang memengaruhi gangguan tidur yaitu respon terhadap penyakit, stres emosi, depresi, pengaruh lingkungan dan penggunaan obat-obatan. Penelitian Khasanah dan Hidayati (2012) mengidentifikasi tiga faktor utama penyebab gangguan tidur, yaitu keadaan lingkungan yang berisik, merasakan nyeri, dan terbangun karena mimpi. Hasil berbeda didapatkan dalam penelitian Oliveira (2010) yang menyebutkan bahwa faktor pencahayaan dan inkontinensia urin sebagai penyebab gangguan tidur pada lansia.

Berbagai dampaknegatifdapat ditimbulkan oleh gangguan tidur; antara lain menurunnya daya tahan tubuh, menurunnya prestasi kerja, kelelahan, depresi, mudah tersinggung, dan menurunnya daya konsentrasi yang dapat memengaruhi keselamatan diri sendiri dan juga orang lain. Menurut Malik (2010), ketidakmampuan lansia memenuhi tidur yang berkualitas dan menurunnya fase tidur REM dapat menimbulkan keluhan pusing, kehilangan gairah, rasa malas, cenderung mudah marah/tersinggung, kemampuan pengambilan keputusan secara bijak menurun, hingga menyebabkan depresi dan frustrasi. Berdasarkan penelitian Syareef (2008) sebagaimana dikutip Jesica (2009), ditemukan 21,7\% lansia yang mengalami gangguan tidur berkepanjangan memiliki keinginan untuk bunuh diri.

Perawat komunitas memiliki tanggung jawab guna membantu lansia mengatasi gangguan tidur. Beberapa cara yang umum dilakukan untuk meningkatkan kualitas tidur lansia antara lain melakukan aktifitas fisik pendek, rendam kaki dengan air hangat, minum minuman hangat, membaca buku atau kitab suci (Jesica, 2009); memadamkan lampu, latihan nafas dalam, atau mengonsumsi obat tidur (Stevens, 2008). Menurut Yang et al (2012), latihan meditasi, yoga dan self hypnosis dinilai cukup efektifuntuk mengatasi gangguan tidur; tetapi hal ini sulit diterapkan pada lansia. Selain itu, Joshi (2008) meyakini bahwa efek rasa nyaman yang dihasilkan dari latihan relaksasi progresif juga bermanfaat 
Sulidah: Pengaruh Latihan Relaksasi Otot Progresif terhadap Kualitas Tidur Lansia

untuk memenuhi kebutuhan istirahat tidur meskipun belum banyak yang mencoba. Relaksasi otot progresif (progressive muscle relaxation), yaitu suatu teknik relaksasi yang menggunakan serangkaian gerakan tubuh yang bertujuan untuk melemaskan dan memberi efek nyaman pada seluruh tubuh (Corey, 2005). Rasa nyaman inilah yang dibutuhkan lansia guna meningkatkan kualitas tidurnya. Berdasarkan penjelasan tersebut maka peneliti tertarik untuk menerapkan latihan relaksasi otot progresif dalam meningkatkan kualitas tidur lansia. Unsur kebaruan (novelty) penelitian ini adalah bahwa penelitian ini menggunakan intervensi relaksasi otot progresif dengan 9 langkah. Hal ini berbeda dari penelitian sebelumnya yang menggunakan 16 langkah. Menurut Soewondo (2012) tidak ada perbedaan prinsip latihan relaksasi otot progresif 9 langkah dan 16 langkah; tetapi latihan relaksasi otot progresif 16 langkah berlangsung lebih lama dan lebih melelahkan sehingga beresiko gagal diterapkan pada lansia. Penelitian ini bertujuan untuk mengidentifikasi bagaimana pengaruh relaksasi otot progresif terhadap kualitas tidur lansia.

\section{Metode Penelitian}

Penelitian ini menggunakan rancangan Quasi Experimental dengan pendekatan PretestPosttest Control Group Design. Populasi penelitian ini adalah semua lansia yang tinggal di Balai Perlindungan Sosial Tresna Werdha Ciparay. Jumlah populasi 150 orang. Teknik sampling yang digunakan adalah purposive sampling. Pemilihan sampel dilakukan berdasarkan kriteria inklusi: berusia minimal 60 tahun, dapat melihat dan mendengar, mengalami gangguan tidur, mampu memahami bahasa Indonesia, dan bersedia menjadi responden dan mengikuti prosedur penelitian sampai tahap akhir.

Pengambilan data berlangsung selama 40 hari mulai tanggal 11 April sampai $20 \mathrm{Mei}$ 2013. Pada awal penelitian digunakan 56 responden tetapi 5 responden dieksklusikan. Dengan demikian besar sampel penelitian ini 51 responden, terdiri dari 26 responden kelompok perlakuan dan 25 responden kelompok kontrol. Kelompok intervensi diberikan pelatihan tentang gerakan relaksasi otot progresif selama tiga hari dan dua hari masa uji coba. Selanjutnya lansia melakukan latihan secara mandiri selama empat minggu dan dilakukan setiap hari menjelang waktu tidur. Guna memastikan lansia melakukan latihan secara benar maka para lansia dipantau oleh relawan terlatih ketika melakukan latihan. Kualitas tidur responden diukur menggunakan instrumen Pittsburgh Sleep Quality Index (PSQI) dari Carole Smyth (2007) dengan alpha cronbach 0,88. Data diambil menggunakan metode wawancara dan dilakukan sebanyak 4 kali; yaitu sebelum intervensi (pretest), dua minggu setelah intervensi (posttest 1), tiga minggu setelah intervensi (posttest 2), dan empat

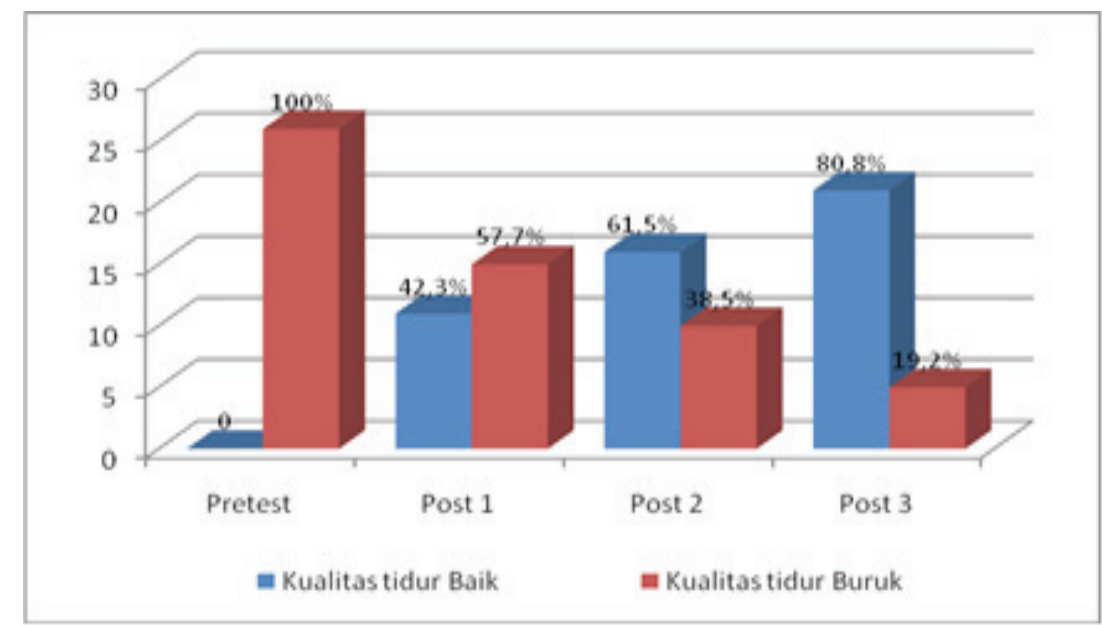

Diagram 1 Distribusi Responden Kelompok Perlakuan Berdasarkan Kualitas Tidur Sebelum dan Sesudah Latihan Relaksasi Otot Progresif 
Sulidah: Pengaruh Latihan Relaksasi Otot Progresif terhadap Kualitas Tidur Lansia

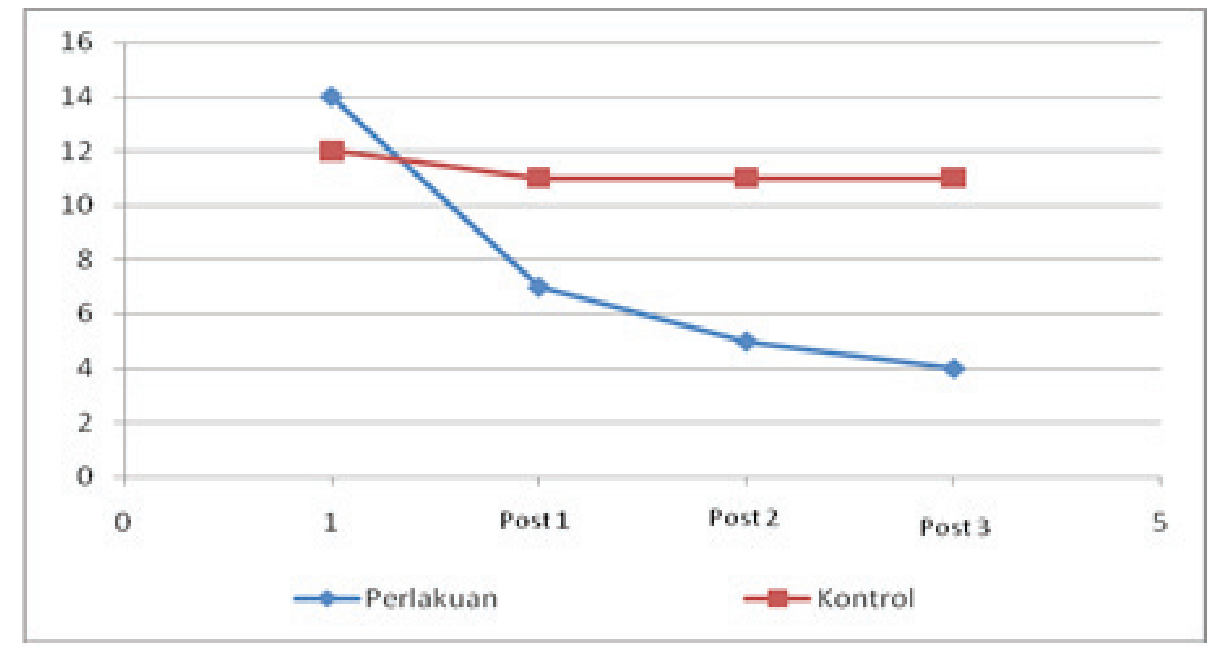

Diagram 2 Rata-rata Skor PSQI Sebelum dan Sesudah Latihan Relaksasi Otot Progresif

minggu setelah intervensi (posttest 3). Setiap kelompok data berdistribusi normal. Analisis hubungan sebelum dan sesudah relaksasi otot progresif digunakan uji t berpasangan dan repeated anova. Analisis hubungan kelompok perlakuan dan kelompok kontrol digunakan uji t tidak berpasangan.

\section{Hasil Penelitian}

Kualitas tidur responden diukur sebelum dan sesudah latihan relaksasi otot progresif. Hasil pengukuran pada kelompok perlakuan dimuat pada diagram 1 .

Berdasarkan diagram di atas diketahui bahwa sebelum latihan relaksasi otot progresif, seluruh responden kelompok perlakuan mempunyai kualitas tidur buruk. Frekuensi responden dengan kualitas tidur baik setelah relaksasi otot progresif menunjukkan kecenderungan meningkat, sedang responden dengan kualitas tidur buruk cenderung berkurang. Hal ini mengindikasikan bahwa latihan relaksasi otot progresif memberi pengaruh terhadap peningkatan kualitas tidur lansia.

Skor PSQI menggambarkan kualitas tidur responden. Semakin kecil skor PSQI maka semakin baik kualitas tidurnya. Perbandingan rata-rata skor PSQI sebelum dan sesudah relaksasi otot progresif dimuat pada diagram 2. Diagram 2 menggambarkan kelompok perlakuan dengan latihan relaksasi otot progresif menunjukkan kecenderungan penurunan rata-rata skor PSQI; sedang kelompok kontrol tanpa latihan relaksasi otot progresif rata-rata skor PSQI cenderung konstan.

Hasil perhitungan didapatkan nilai t hitung lebih besar dari t tabel dan $p<0,05$. Oleh karena itu dapat disimpulkan bahwa terdapat perbedaan yang bermakna dari kualitas tidur lansia sebelum dan sesudah latihan relaksasi otot progresif pada kelompok perlakuan.

Berdasarkan tabel 2 diketahui nilai $\mathrm{p}=$

Tabel 1 Perbedaan Skor PSQI Sebelum dan Sesudah Latihan Relaksasi Otot Progresif Berdasarkan Uji t Berpasangan

\begin{tabular}{lccc}
\hline \multicolumn{1}{c}{ Metode } & n & Rerata+S.D & p \\
\hline Skor PSQI pada Pretest & 26 & $13,73+2,20$ & 0,000 \\
Skor PSQI pada Posttest 1 & 26 & $7,62+3,07$ & \\
Skor PSQI pada Posttest 2 & 26 & $5,62+2,37$ & \\
Skor PSQI pada Posttest 3 & 26 & $4,58+1,88$ & \\
\hline
\end{tabular}


Sulidah: Pengaruh Latihan Relaksasi Otot Progresif terhadap Kualitas Tidur Lansia

Tabel 2 Perbedaan Skor PSQI Sebelum dan Sesudah Latihan Relaksasi Otot Progresif Berdasarkan Uji Repeated Anova

\begin{tabular}{|c|c|c|}
\hline Skor PSQI & Perbedaan Rerata+SD & $\mathbf{p}$ \\
\hline Pretest & $0,28+0,578$ & 0,000 \\
\hline Posttest 1 & $6,12+0,578$ & \\
\hline Posttest 2 & $8,12+0,578$ & \\
\hline Posttest 3 & $9,15+0,578$ & \\
\hline
\end{tabular}

Tabel 3 Perbedaan Skor PSQI Kelompok Perlakuan dan Kelompok Kontrol Berdasarkan Uji t Tidak Berpasangan

\begin{tabular}{lcccc}
\hline \multicolumn{1}{c}{ Kelompok } & Sampel & n & Rerata+SD & p \\
\hline Pretest & Perlakuan & 26 & $13,73+2,20$ & 0,006 \\
& Kontrol & 25 & $11,56+3,09$ & \\
Posttest 1 & Perlakuan & 26 & $7,62+3,07$ & 0,000 \\
& Kontrol & 25 & $11,28+3,55$ & 0,000 \\
Posttest 2 & Perlakuan & 26 & $5,62+2,37$ & 0,000 \\
& Kontrol & 25 & $11,24+3,28$ & \\
\hline \multirow{2}{*}{ Posttest 3 } & Perlakuan & 26 & $4,58+1,88$ & $11,28+3,49$ \\
& Kontrol & 25 & & \\
\hline
\end{tabular}

0,000. Hasil perhitungan di peroleh nilai $\mathrm{F}$ hitung lebih besar dari $\mathrm{F}$ tabel sehingga Ho ditolak. Dengan demikian dapat disimpulkan bahwa paling tidak terdapat dua kelompok pengukuran kualitas tidur yang berbeda. Uji lanjut menggunakan LSD diketahui bahwa kelompok pengukuran kualitas tidur yang berbeda adalah kelompok pretest terhadap posttest 1 , pretest terhadap posttest 2 , pretest terhadap posttest 3 dan posttest 1 terhadap posttest 3. Adapun kelompok posttest 1 terhadap posttest 2, posttest 2 terhadap posttest 3 menunjukkan perbedaan yang tidak bermakna. Hal ini mengindikasikan kualitas tidur lansia setelah relaksasi otot progresif lebih baik dibanding sebelum latihan.

Rata-rata skor PSQI kelompok perlakuan lebih rendah dari kelompok kontrol. Hasil pengujian dapat disimpulkan bahwa terdapat perbedaan yang bermakna dari skor PSQI antara kelompok perlakuan terhadap kelompok kontrol. Hal ini berarti kualitas tidur kelompok perlakuan lebih baik dibanding kelompok kontrol (Tabel 3).

\section{Pembahasan}

Pengukuran kualitas tidur berdasarkan instrumen Pittsburgh Sleep Quality Index
(PSQI), dari tujuh komponen terdapat tiga yang paling dominan menyebabkan gangguan tidur, yaitu komponen 2 latensi tidur, komponen 3 durasi tidur, dan komponen 4 efisiensi tidur. Adapun komponen yang paling sedikit menyumbang skor adalah komponen 6 penggunaan obat-obatan untuk membantu tidur.

Latensi tidur menggambarkan waktu yang diperlukan untuk memulai tidur yang diukur dengan waktu yang dibutuhkan untuk memulai tidur serta frekuensi ketidakmampuan tidur dalam 30 menit. Pada penelitian ini didapatkan durasi waktu memulai tidur terpendek adalah 20 menit dan durasi terlama adalah 90 menit dengan durasi rata-rata 55 menit. Frekuensi tidak dapat tidur dalam 30 menit umumnya lebih dari 3 kali per minggu. Keadaan tersebut mengindikasikan lansia mengalami kesulitan memulai tidur. Hal ini terjadi karena sebagian besar lansia menderita insomnia. Insomnia merupakan jenis gangguan tidur yang paling sering ditemukan pada lansia. Hal ini sesuai dengan penelitian Eshelman (2008) menemukan lebih dari $50 \%$ lansia mengalami kesulitan tidur malam hari.

Durasi tidur menggambarkan lamanya waktu tidur. Lansia umumnya mengalami pemendekan durasi tidur bahkan ada 
Sulidah: Pengaruh Latihan Relaksasi Otot Progresif terhadap Kualitas Tidur Lansia

yang tidak mampu mencapai tidur yang dalam (tidur tahap IV dan tidur REM). Kebanyakan lansia juga mudah terbangun hanya oleh stimulus yang ringan sekalipun. Padahal tidur yang dalam sangat bermanfaat untuk mengembalikan fungsi tubuh dan mempertahankan kebugaran. Johnson \& Epperson (2006) menjelaskan bahwa orang yang kekurangan durasi tidur mengakibatkan tidak mampu berintegrasi dengan baik dan tidak efektif dalam aktifitasnya; mereka menunjukkan tanda-tanda kebingungan, curiga, mudah menyerah, tidak merasa aman, mudah marah, dan kehilangan selera makan; sehingga banyak lansia mengalami kerugian akibat ketidakmampuannya mencapai tidur yang dalam.

Efisiensi tidur dengan membandingkan jumlah waktu tidur terhadap lamanya waktu ditempat tidur. Kesulitan memulai tidur, ketidakmampuan memertahankan kenyenyakan tidur, dan sering terbangun merupakan faktor penyebab penurunan efisiensi tidur. Hal ini sesuai dengan penelitian Zarcone, Falke \& Anlar (2010) yang mengidentifikasi $66,19 \%$ lansia hanya memiliki kurang dari 50\% efisiensi tidurnya. Seiring dengan proses penuaan yang terjadi pada lansia, efisiensi tidur akan berkurang sehingga tidak tercapai kualitas tidur yang adekuat. Sesungguhnya penurunan jumlah jam tidur bukanlah suatu masalah jika lansia tersebut merasakan kualitas tidur yang baik, karena kualitas tidur yang baik akan dapat memulihkan fungsi tubuh.

Frekuensi penggunaan obat untuk membantu tidur menggambarkan berat ringannya gangguan tidur yang dialami oleh lansia. Semakin sering mengonsumsi obat untuk membantu tidur berarti lansia tersebut mengalami gangguan tidur berat yang juga berarti kualitas tidurnya semakin buruk. Pada awal penelitian (pretest) ditemukan enam orang responden kelompok perlakuan yang menggunakan obat untuk membantu tidur. Frekuensi penggunaan obat adalah antara 1-2 kali seminggu. Jumlah responden yang menggunakan obat untuk membantu tidur berkurang menjadi tiga orang pada posttest 1 , berkurang lagi menjadi hanya satu orang pada posttest 2 dan posttest 3 dengan frekuensi penggunaan kurang dari sekali dalam seminggu. Berkurangnya jumlah dan frekuensi penggunaan obat untuk membatu tidur disebabkan responden sudah memiliki kualitas tidur yang lebih baik dibanding sebelumnya sebagai hasil latihan relaksasi otot progresif.

Lansia umumnya mengalami penurunan kemampuan beradaptasi terhadap perubahan fisik dan psikologis sebagai dampak proses penuaan. Malik (2010) menjelaskan bahwa dorongan homeostatik untuk tidur lebih dulu menurun kemudian diikuti oleh dorongan irama sirkadian untuk terjaga. Menurut Woolfolk \& McNulty (2003) sebagaimana dikutip oleh Purwanto (2012), gangguan juga sering terjadi pada ritmik sirkadian tidurjaga, yaitu suatu kondisi dimana jam biologik menjadi lebih pendek dan fase tidurnya menjadi lebih maju. Gangguan ritmik sirkadian tidur jaga ini berpengaruh terhadap kadar hormon yang terutama disekresikan saat tidur dalam pada malam hari, antara lain hormon tiroid, prolaktin, dan melatonin (Jesica, 2009).

Secara umum, gangguan tidur yang menyebabkan kualitas tidur lansia menurun terjadi karena faktor fisik, psikologis dan lingkungan. Faktor fisik seperti adanya penyakittertentu yang diderita mengakibatkan lansia tidak dapat tidur dengan baik. Hal ini pula yang banyak dialami lansia di BPSTW Ciparay. Faktor psikologis seperti kecemasan, stres, ketakutan, dan ketegangan emosional acapkali dialami lansia. Apalagi lansia di panti umumnya mempunyai stresor tambahan seperti keharusan beradaptasi terhadap lingkungan panti; adaptasi dengan teman sekamar, dengan penghuni panti yang lain dan atau pengelola panti; serta adaptasi terhadap kegiatan dan aturan panti (Erliana, 2008). Tidak jarang kejadian kecil yang dialami lansia menyulut emosi dan menyebabkan kecemasan atau stres yang tentu saja dapat berakibat timbulnya gangguan tidur.

Lingkungan dapat menjadi faktor pendukung maupun penghambat tidur. Termasuk faktor lingkungan misalnya pencahayaan, temperatur kamar, ventilasi, dan kebisingan. Secara umum kondisi lingkungan di BPSTW Ciparay cukup kondusif. Lokasi panti yang jauh dari kebisingan, temperatur yang nyaman, ventilasi yang memadai, dan pencahayaan yang baik merupakan faktor 
Sulidah: Pengaruh Latihan Relaksasi Otot Progresif terhadap Kualitas Tidur Lansia

yang mendukung untuk tidur. Meskipun demikian, sebagian kecil lansia mengeluh kurang nyaman akibat temperatur dan pencahayaan. Hal ini dapat dimengerti mengingat respon setiap individu terhadap lingkungan adalah berbeda-beda, apalagi lansia di panti mempunyai latar belakang yang berbeda pula.

Responden kelompok perlakuan menunjukkan peningkatan kualitas tidur setelah latihan relaksasi otot progresif, sedang pada kelompok kontrol tidak terjadi perubahan yang bermakna. Tren peningkatan kualitas tidur kelompok perlakuan terlihat dari peningkatan frekuensi lansia dengan kualitas tidur baik dan penurunan skor ratarata PSQI. Hal ini menunjukkan bahwa latihan relaksasi otot progresif mempunyai dampak positif terhadap peningkatan kualitas tidur lansia.

Latihan relaksasi otot progresif cukup efektif untuk memperpendek latensi tidur, memperlama durasi tidur, meningkatkan efisiensi tidur, mengurangi gangguan tidur, dan mengurangi gangguan aktifitas pada siang hari sehingga meningkatkan respon puas terhadap kualitas tidurnya. Hasil serupa didapatkan pada penelitian Saeedi et al. (2012), bahwa relaksasi otot progresif mampu mereduksi penyebab gangguan tidur sehingga kualitas tidur meningkat. Efek relaksasi otot progresif dalam pemenuhan kebutuhan tidur dikemukakan oleh Conrad \& Roth (2007) bahwa teknik relaksasi otot progresif mampu mengontrol aktivitas sistem syaraf otonom dan aktivasi suprasciasmatic nucleus sehingga memudahkan untuk memulai dan mempertahankan tidur yang dalam.

Peningkatan kualitas tidur lansia setelah latihan relaksasi otot progresif disertai dengan berkurangnya keluhan lansia. Keadaan ini terlihat dari jawaban responden pada instrumen PSQI. Pada tahap pretest banyak lansia yang mengeluhkan memiliki nyeri dengan frekuensi yang cukup sering; tetapi seiring dengan latihan relaksasi otot progresif yang dilakukan membuat frekuensi nyeri menjadi berkurang, bahkan hilang. Sebagian kecil responden juga menyatakan tidak dapat bernafas dengan nyaman, mengalami mimpi buruk, dan terbangun tengah malam untuk menggunakan toilet pada sebagian besar responden. Keluhan tersebut juga berkurang setelah melakukan latihan relaksasi otot progresif. Hal ini sesuai dengan hasil penelitian terdahulu yang membuktikan bahwa latihan relaksasi otot progresif bermanfaat untuk meredakan keluhan sakit kepala dan meningkatkan kualitas hidup (Azizi \& Mashhady, 2012); mengatasi ketegangan, kecemasan, stres dan depresi (Jacobson \& Wolpe dalam Conrad \& Roth, 2007); dan membantu mengatasi kesulitan memulai dan mempertahankan tidur pada penderita insomnia (Erliana, 2008).

Pengaruh relaksasi otot progresif terhadap kualitas tidur terlihat jelas dari peningkatan durasi tidur lansia. Pada awal penelitian, durasi tidur lansia terpendek adalah 3 jam, dan durasi terlama adalah 6 jam 45 menit. Setelah latihan relaksasi otot progresif ratarata durasi tidur lansia kelompok perlakuan menunjukkan peningkatan. Durasi terpendek yang didapatkan adalah 5 jam dan durasi terlama adalah 7 jam 15 menit. Pada kelompok kontrol, rata-rata durasi tidur tersebut tidak mengalami perubahan.

Peneliti meyakini bahwa peningkatan kualitas tidur pada penelitian ini terjadi karena pengaruh latihan relaksasi otot progresif. Responden penelitian ini, baik kelompok perlakuan maupun kelompok kontrol memiliki karakteristik yang tidak jauh berbeda, tinggal dalam lingkungan yang sama, dan sama-sama memiliki gangguan tidur pada awal penelitian. Kelompok perlakuan menunjukkan peningkatan kualitas tidur secara bermakna setelah latihan relaksasi otot progresif; sedangkan kelompok kontrol tanpa melakukan latihan relaksasi otot progresif ternyata tidak mengalami perubahan pada kualitas tidur. Hal ini membuktikan bahwa latihan relaksasi otot progresif memberi pengaruh terhadap peningkatan kualitas tidur lansia.

Penelitian ini, faktor usia, jenis kelamin, tingkat pendidikan, status pernikahan, dan lama tinggal di panti tidak mempunyai hubungan dengan kualitas tidur. Hasil analisis korelasi antara faktor-faktor tersebut terhadap kualitas tidur menunjukkan tingkat signifikansi lebih dari 0,05 yang berarti bahwa kualitas tidur tidak berhubungan dengan usia, jenis kelamin, tingkat pendidikan, status pernikahan, dan lama tinggal di panti. Hal ini menegaskan bahwa peningkatan kualitas 
Sulidah: Pengaruh Latihan Relaksasi Otot Progresif terhadap Kualitas Tidur Lansia

tidur memang disebabkan oleh latihan relaksasi otot progresif. Faktor psikologis memang memengaruhi kualitas tidur; tetapi responden kelompok kontrol juga mempunyai kondisi psikologis yang hampir sama dengan kelompok perlakuan. Maka, jika kelompok perlakuan mengalami peningkatan kualitas tidur sedang kelompok kontrol tidak meningkat, berarti aspek psikologis sebagai variabel perancu pada penelitian ini dapat dikesampingkan.

Peningkatan kualitas tidur lansia setelah latihan relaksasi otot progresif didukung oleh konsep Smith (2005) dan Soewondo (2012) yang menyatakan bahwa gerakan kontraksi dan relaksasi otot dapat menstimulasi respon relaksasi baik fisik maupun psikologis. Menurut Demiralp, Oflaz, \& Komurcu (2010) respon tersebut terjadi karena rangsangan aktivitas sistem syaraf otonom parasimpatis yaitu nuclei rafe yang terletak pada separuh bagian bawah pons dan medulla; akibatnya terjadi penurunan pada metabolisme tubuh, denyut nadi, tekanan darah dan frekuensi pernafasan, serta terjadi peningkatan sekresi serotonin sehingga tubuh menjadi tenang dan lebih mudah untuk tidur. Pada saat yang sama, ketika melakukan gerakan relaksasi otot, sebuah sel syaraf juga mengeluarkan opiate peptides yang merupakan saripati kenikmatan dan dialirkan keseluruh tubuh sehingga yang dirasakan adalah rasa nikmat dan rileks (Persson, et al., 2008).

Menurut Yang et al. (2012), gangguan tidur diduga sebagai akibat dari peningkatan aktivitas Reticullar Activating System (RAS), dopamine dan noreprineprine atau disebabkan penurunan aktivitas sistem batang otak. Dalam penelitiannya, Jacobson berkesimpulan bahwa adanya ketegangan menyebabkan serabut-serabut otot berkontraksi. Jacobson meyakini bahwa otot yang tegang berhubungan dengan jiwa yang tegang dan fisik yang rileks akan disertai dengan mental yang rileks pula (Soewondo, 2012). Dalam latihan relaksasi otot progresif, gerakan menegangkan sekumpulan otot dan kemudian melemaskannya serta membedakan sensasi tegang dan rileks, seseorang tersebut dapat menghilangkan kontraksi otot untuk selanjutnya akan mengalami perasaan rileks dan nyaman (Zarcone, Falke, \& Anlar, 2010).

Menurut Oliveira (2010) aktivasi sistem saraf simpatis membuat lansia tidak dapat merasakan rileks dan cenderung menghalangi hadirnya rasa kantuk. Melalui latihan relaksasi otot progresif lansia dilatih untuk menghadirkan respon relaksasi sehingga dapat mencapai keadaan yang tenang dan kondusif untuk tertidur. Potter \& Perry (2005) menyatakan bahwa seseorang akan tertidur hanya jika telah merasa nyaman dan rileks. Smith (2005) menjelaskan bahwa kondisi rileks yang dihasilkan terjadi karena latihan relaksasi otot progresif dapat memberikan pemijatan halus pada berbagai kelenjar tubuh, menurunkan produksi kortisol dalam darah, mengatur pengeluaran hormon yang adekuat sehingga memberi keseimbangan emosi dan ketenangan pikiran.

Menurut Davis dan McKay (2001), latihan relaksasi otot progresif terbukti mampu mengatasi keluhan anxietas, insomnia, kelelahan, kram otot, serta menstabilkan tekanan darah. Kenyataan tersebut didasarkan pada keyakinan manfaat latihan dalam menurunkan kecemasan dan ketegangan fisiologis, serta meningkatkan relaksasi otot sehingga terjadi vasodilatasi pembuluh darah. Aliran darah sistemik menjadi lancar, denyut nadi menjadi normal, frekuensi pernapasan menjadi normal, dan mengurangi evaporasi sehingga klien menjadi nyaman dan pikiran menjadi tenang sebagai akibat dari penurunan aktivitas Reticullar Activating System (RAS) dan peningkatan aktivitas batang otak (Joshi, 2008; Yang et al., 2012). Saeedi et al. (2007) menjelaskan bahwa efek relaksasi mampu meningkatkan kerja syaraf parasimpatis sehingga kerja jantung berkurang dan suplai oksigen terpenuhi. Seseorang yang melakukan latihan relaksasi otot progresif akan menunjukkan penurunan kadar norepineprin, penurunan kontraktilitas jantung, dan menstimulasi suprachiasmatic nucleus untuk menimbulkan sensasi nyaman sehingga merangsang timbulnya kantuk.

\section{Simpulan}

Latihan relaksasi otot progresif terbukti bermanfaat untuk meningkatkan kualitas tidur lansia. Manfaat tersebut tergambar dengan meningkatnya respon subjektif kepuasan tidur, latensi tidur memendek, durasi tidur 
Sulidah: Pengaruh Latihan Relaksasi Otot Progresif terhadap Kualitas Tidur Lansia

bertambah, efisiensi tidur meningkat, keluhan gangguan tidur berkurang, dan berkurangnya gangguan aktifitas siang hari sehubungan dengan masalah tidur. Hasil penelitian ini mendukung penemuan penelitian sebelumnya tentang manfaat relaksasi otot progresif yang mampu mereduksi penyebab gangguan tidur. Dengan demikian relaksasi otot progresif dapat dijadikan sebagai terapi komplementer dalam tatalaksana gangguan tidur pada lansia.

\section{Daftar Pustaka}

Azizi, M., \& Mashhady, H. (2012). Analysis of progressive relaxation effect on life quality of migraine patients. Current Research Journal of Social Sciences 4(2), 150-152.

Conrad, A., \& Roth, W. T. (2007). Muscle relaxation therapy for anxiety disorders: It works but how? Journal of Anxiety Disorders, 21, 243-264.

Corey, G. (2005). Student manual for theory and practice of counselling and psychotherapy ( $7^{\text {th }}$ edition). USA: Thompson Brooks/Cole.

Crowley, K. (2011). Sleep and sleep disorders in older adults. Retrieved from http://web. ebscohost.com/ehost/pdfviewer/sid=b76f647

Davis \& McKay. (2001). Panduan relaksasi dan reduksi stres (Edisi V). Jakarta: EGC.

Demiralp, Oflaz, \& Komurcu. (2010). Effects of relaxation training on sleep quality and fatigue in patients with breast cancer undergoing adjuvant chemotherapy. Journal of Clinical Nursing, 19, 1073-1083.

Erliana, E. (2008). Perbedaan tingkat insomnia sebelum dan sesudah latihan relaksasi otot progresif (pregressive muscle relaxation) di BPSTW Ciparay Bandung. Tersedia dalam http://pustaka.unpad.ac.id/ wp-content/uploads/pdf.

Eshelman, R. (2008). A Systematic review of nonpharmacological therapies for insomnia. Silver Spring, 45, 49-64.
Fatimah. (2012). Populasi lansia. Tersedia dalam http://theopoxibink.blogspot.com/.

Jesica, B. (2009). Pentingnya tidur berkualitas bagi kesehatan. Jakarta: Sagung Seto.

Johnson \& Epperson. (2006). Quality of sleep and quality of life in elderly. Sleep Med 12(1), 93-102.

Joshi, S. (2008). Nonpharmacologic therapy for insomnia in elderly. Clin Geriatr Med. 24(1), 107-119.

Kemenkes RI. (2015). Pelayanan dan peningkatan kesehatan usia lanjut. Tersedia dalam http://www.depkes.go.id/article/ view/15052700010/.

Khasanah, K., \& Hidayati, W. (2012). Kualitas tidur lansia balai rehabilitasi sosial "mandiri” Semarang. Jurnal Nursing Studies. 1(1), 189-196.

Madjid, I. (2008). Mewujudkan lanjut usia yang sejahtera. Jakarta: Penerbit Harapan Jaya.

Malik, K. (2010). Seri hidup sehat : rahasia dibalik tidur. Jakarta: Pusaka Indonesia.

Marchira, C. R. (2007). Insomnia pada lansia dan penatalaksanaannya. Jurnal Berkala Kesehatan Klinik 13(2) : 123-129.

Montagna, P., \& Cokroverty, S. (2011). Sleep disorders part 1 (handbook of clinical neurology). Elsevier Science Publishing Co.

Oliveira, A. (2010). Sleep quality of elders living in long term institution. Tersedia dalam http://www.scielo.br/pdf/reeusp/v44n3/ en_10.pdf.

Persson et al. (2008). Relaxation as treatment for chronic musculoskeletal pain : a systematic review of randomized controlled studies. Physical Therapy Reviews, 13(5), 355-365.

Potter \& Perry. (2005). Buku ajar fundamental keperawatan : Konsep, proses dan praktek. Jakarta: Penerbit Buku Kedokteran EGC. 
Sulidah: Pengaruh Latihan Relaksasi Otot Progresif terhadap Kualitas Tidur Lansia

Purwanto, S. (2012). Mengatasi insomnia dengan terapi relaksasi. Jurnal Kesehatan, 1(2), 141-147.

Saeedi et al. (2012). The effect of progressive muscle relaxation on sleep quality of patients undergoing hemodialysis. Iranian Journal of Critical Care Nursing, 5(1), 23-28.

Samsudrajat, A. (2012). Menuju hari tua yang sehat, mandiri dan produktif tanpa kontaminasi rokok untuk mewujudkan ekonomi hijau. Tersedia dalam https:// agus 34 drajat.wordpress.com/author/ agus34drajat/page/2/.

Smith, J. C. (2005). Relaxation, meditation, and mindfulness : A mental health practitioner's guide to new and traditional approaches. New York: Springer.

Smyth, C. (2007). The pittsburgh sleep quality index (PSQI). Try this : Best practices in nursing care to older adults. Issue Number 6.1. Tersedia dalam http://consultgerirn.org/ uploads/File/trythis/try_this_6_1.pdf.
Soewondo, S. (2012). Stres, Manajemen Stres, dan Relaksasi Progresif. Jakarta: LPSP3 UI

Stevens, M. S. (2008). Normal sleep, sleep physiology, and sleep deprivation : general principles. Tersedia dalam www.emedicine. com/neuro/topic444.htm.

Wolkove et al. (2007). Sleep and aging: 1. Sleep disorders commonly found in older people. CMAJ, 176(9), 1299-1304.

Woolfolk, R. L., \& McNulty, T. F. (2003). Relaxation treatment for insomnia: A componen analysis. Journal of Consulitng and Clinical Psychology, 51(4), 495-503.

Yang et al. (2012). Exercise training improves sleep quality in middle-aged and older adults with sleep problems: A systematic review. Journal of Physiotherapy, 58, 157-163.

Zarcone, P., Falke, R., \& Anlar, O. (2010). Effect of progressive relaxation on sleep quality. Neurosci, 63, 221-227. 